\title{
ОБРАЗОВАНИЕ ОРЕНБУРГСКОЙ ГУБЕРНСКОЙ КОМСОМОЛЬСКОЙ ОРГАНИЗАЦИИ
}

\section{FORMATION OF THE ORENBURG PROVINCIAL KOMSOMOL ORGANIZATION \\ E. Tomina}

Summary: The article deals with the history of the origin of the Komsomol organization of Orenburg region among young people. The general conditions and events of the formation and functioning of Komsomol cells are analyzed. The reason for the late creation of the Komsomol organization on the territory of the Orenburg province is highlighted. The activities of the Komsomol organization among the students and working youth of the RKSM in each village, parish, village and village of Orenburg region are determined.

Keywords: Komsomol organizations, provincial committee, party organization, party congress.

\author{
Томина Елена Федоровна \\ К.n.н., доцент, Оренбургский государственный \\ университет \\ teador17@mail.ru
}

Аннотация: В статье рассматривается история зарождения комсомольской организации Оренбуржья среди молодежи. Проанализированы общие условия и события образования и функционирования комсомольских ячеек. Выделена причина позднего создания комсомольской организации на территории оренбургской губернии. Определена деятельность комсомольской организации среди учащейся и рабочей молодежи РКСМ в каждой деревне, волости, селе и станицах Оренбуржья.

Ключевые слова: комсомольские организации, губернский комитет, партийная организация, съезд партии.
$\mathrm{M}$ олодежь - наиболее восприимчивая и в то же время динамичная часть населения любого общества, так как в силу своего объективного состояния концентрирует в себе потенциальные тенденции его последующего развития.

Каждое поколение молодых людей, вступающее в самостоятельную жизнь, усваивает ценности предшествовавших поколений, формирует собственные, и, основываясь на них, разрабатывает и реализует свою жизненную программу.

Именно поэтому в переломные периоды истории те или иные политические силы общества часто использовали молодежь в своих целях[5, с. 98]. Недалекое советское прошлое показательно в этом отношении, оно содержит массу примеров использования потенциала молодого поколения Коммунистической партией Советского Союза, создавшей для этого особую организацию - Коммунистический Союз Молодежи (РКСМ - РЛКСМ ВЛКСМ). Изначально комсомол создавался как организация, которая должна была действовать в молодежной среде под идейным и организационным руководством партии. Комсомол являлся резервом, «кузницей» новых кадров для партии, служил помощником и проводником в жизнь ее политики среди молодежи. Но спустя время комсомол ушел в прошлое. Стало более проблематичным само социальное существование молодежи. В пылу преобразований современные реформаторы объявили прежнюю систему воспитания пережитком тоталитарно- го мышления и доверились исключительно спонтанным воздействиям на личность[4, с. 180-193].

Но в последние годы молодежь вновь становится объектом повышенного внимания. Политические партии, ведущие борьбу за власть, вновь увидели в молодом поколении носитель будущего. Отсюда понятно стремление каждой из современных партий заручиться поддержкой молодых. Политические лидеры делают ставку на тех, кто может перенять их идеи и дела, кому еще жить и творить, кто сможет передать сформировавшуюся систему ценностей и мировоззрения последующему поколению. За последние годы начинает приобретать свое лицо молодежная политика, которая стала реализовываться в молодежных секциях при крупных по численности партиях.

Повышению интереса к истории ВЛКСМ способствуют не только юбилейные даты 50-летия комсомола, и даже 100-летие, но и изучение участия молодежи в установлении Советской власти в Оренбурге. В 2019 году оренбургской комсомольской организации исполнилось 100 лет.

В Оренбурге в 1918 году власть находилась в руках белогвардейцев под командованием А.И. Дутова. Это обстоятельство послужило причиной того, что комсомольская организация в Оренбургской губернии сформировалась несколько позднее, в сравнении с другими регионами страны (Российский Коммунистический Союз 
Молодежи был основан на первом съезде 29 октября 1918 года).

Как только 22 января 1919 года административный центр губернии г. Оренбург был окончательно освобожден от белогвардейцев, Оренбургский губернский комитет РКП (б) уделил особое внимание вопросам формирования местной комсомольской организации [3, с. 2].

Создание комсомола было особенно необходимо не только потому, что молодежь с 14 до 29 лет составляла примерно третью часть всего населения губернии, но и в силу того, что от организационного закрепления идеологического влияния на нее в немалой степени зависел исход борьбы за упрочнение Советской власти в Оренбуржье. Только через самостоятельную молодежную коммунистическую организацию можно было быстрее и шире вовлечь подрастающее поколение в активную деятельность по укреплению власти Советов [8, с. 23].

Решающую роль в создании комсомола в Оренбуржье сыграли решения VIII съезда РКП (б). В феврале 1919 года Оренбургская партийная организация, руководствуясь письмом ЦК РКП (б), приступила к деятельной подготовке к предстоящему съезду [2, с. 16]. На общем собрании большевиков Оренбуржья, обсуждавших вопрос о подготовке к съезду, с докладом выступил И.А. Акулов. Собрание приняло постановление по его докладу и включило в повестку дня губернской партийной конференции вопрос «Об организации рабочей молодежи».

Вскоре губком РКП (б) создал инициативную группу по организации в Оренбурге Коммунистического союза молодежи. В ее состав вошли молодые члены РКП (б): М. Башилов, Х. Хакимов, Е. Герасимов, И. Порошин и другие. Председателем был избран Марк Башилов. Была оказана идейная, организационная, материальная помощь его инициативной группе со стороны советских и партийных органов губернии [3, с. 2].

Учредительное собрание группы состоялось 27 февраля 1919 года. Первые комсомольцы губернии решили организовать социалистическую, литературную, драматургическую, военно-спортивную секции, открыть молодежную библиотеку и клуб. С целью вовлечения в новую молодежную организацию договорились проводить постоянную агитацию среди рабочей и учащейся молодежи. Инициативная группа провела ряд митингов, посвященных вопросам создания первых комсомольских организаций на местах. Рабочая молодежь встретила эту идею с большим одобрением [2, с. 16].

Особую роль в формировании комсомола в Оренбуржье сыграла губернская партийная конференция, состо- явшаяся 4-5 марта 1919 года. Она рассмотрела вопрос о подготовке к VIII съезду партии, нацелила на «создание в каждой деревне, волости, станице коммунистических ячеек» и приняла решение о «привлечении молодежи в свои ряды путем создания при ячейках Союзов коммунистической молодежи...» [8, с. 9].

В газете «Коммунар» - печатном органе Оренбургского губкома РКП (б) - регулярно публиковались статьи о целях и задачах Союза молодежи, освещался каждый практический шаг инициативной группы [2, с. 17].

VIII съезд партии, состоявшийся с 18 по 23 марта 1919 года, принял новую программу РКП (б). Решения партийного съезда сыграли исключительную роль в жизни комсомола страны в Оренбуржье, оказали решающее воздействие на всю деятельность формирующейся молодежной организации губернии в годы гражданской войны. Под знаком его решений объединялись, действовали и учились первые комсомольцы Оренбуржья [8, c. 24].

Выполняя указания VIII съезда партии и губернской партийной конференции, губком РКП (б) сосредоточил свои усилия на создание и укрепление широкой сети партийных ячеек. Большая работа в этом направлении была проделана, например, в Васильевской волости Оренбургского уезда. Возникшие сельские партийные ячейки сразу включались в работу по организации молодежи в коммунистические союзы. Соответствующая агитация среди сельских юношей и девушек была поручена молодым членам партии [6, д. 11, л. 7].

Трудовая крестьянская молодежь поддержала большевиков в проведении организационных и общественно-политических мероприятий. На состоявшемся в конце марта - начале апреля 1919 года Васильевском волостном съезде РКП (б) был поставлен вопрос о необходимости создания Коммунистического союза молодежи волости и было решено помочь ему необходимыми средствами [6, д. 11, л. 8]. Ранее в селе Петровском существовавший кружок молодежи принял постановление о присоединении к клубу коммунистов. Решение было единогласно поддержано чрезвычайным собранием коммунистов села. Позднее кружок превратился в местную организацию Коммунистического союза молодежи. Инициативная группа сделала первые попытки объединить в Союз учащуюся молодежь. Так, 23 марта 1919 года на общее собрание учащихся старших классов гимназий и реального училища Оренбурга пришли Марк Башилов, Халик Хакимов и Николай Порошин. Однако учащаяся молодежь негативно встретила пролетариев-коммунистов, но такое отношение не обескуражило М. Башилова. Он рассказал о создании комсомола в стране, об оренбургской инициативной группе. Собрание показало, что 
основной массе учащихся старших классов буржуазного и мелкобуржуазного происхождения, были чужды коммунистические идеи и идеалы. Убедившись в этом, инициативная группа пришла к выводу, о необходимости создания комсомольской организации, и вовлечения в комсомол молодежи из других социальных групп. Инициативная группа сосредоточила свое основное внимание на молодежной части трудовых коллективов местных фабрик и заводов [2, с. 17].

Осуществляя подготовительную работу среди рабочей молодежи, инициативная группа вечером 30 марта 1919 года в доме № 2 по улице Советской г. Оренбурга (ныне общежитие студентов медицинского института) организовала запись желающих вступить в комсомол. Но через несколько дней первые комсомольцы ушли на фронт. Работа по формированию комсомольской организации в губернии временно была приостановлена изза наступления армии А. В. Колчака и активизации белоказачьих войск А.И. Дутова [2, с. 18].

В тяжелые дни осады Оренбурга губернская партийная организация находила время и силы, чтобы продолжить работу по созданию на территории края местных организаций Коммунистического союза молодежи. Короткие передышки между боями коммунисты использовали для организации комсомольских ячеек среди бойцов, защищавших город. Так были созданы ячейки в 277-м и 210-м стрелковых полках Красной Армии [2, с. $18]$.

В конце мая 1919 года губком партии образовал новую инициативную группу по созданию комсомольских организаций в Оренбурге, которая провела активную агитационную работу среди молодежи. В ее состав вошли председатель губернского исполнительного комитета А.А. Коростелев, члены губкома РКП (б): В. Александров, П. Жук, М. Здобнов, А. Сафронов [3, с. 3].

Комсомольская организация Оренбуржья была создана в решающий момент борьбы между белыми и красными за Оренбург. В ночь с 22 на 23 июня, когда на подступах к Оренбургу шли ожесточенные бои, по городу были расклеены листовки, призывавшие рабочую молодежь явиться к 12 часам дня в клуб коммунистов (ныне клуб имени Ф.Э. Дзержинского) на митинг посвященный созданию комсомольской организации. В полдень в клубе собрались молодые рабочие и небольшая группа учащихся, всего несколько сотен человек. Выступили Коростелев, Ляпин, Поляков, сообщили о целях и задачах комсомола. Выступающим было трудно говорить из-за разрывавшихся на Хлебной площади снарядов, а также из-за выкриков собравшихся бойскаутов, которые хотели сорвать собрание. На митинге объявили запись в комсомол. Их было 109 самых первых комсомольцев, которые и составили основу городской и губернской организации комсомола в дальнейшем. Правда, записывался и 110-й, но он засомневался в своем решении и в итоге выписался. Среди них: В. Александров, С. Кабаев, А. Ландышев, М. Нестеров - позже секретарь губкома PКСМ, а М. Здобнов, Р. Потапенко, С. Федоров, братья Беловы - позже стали членами горкома и губкома комсомола. Большая часть вступивших в комсомол была представлена рабочей молодежью, и лишь незначительная часть - учащимися разных учебных заведений Оренбурга. Тут же было избранно организационное бюро Оренбургской организации РКСМ в составе В. Александрова, А. Бугкевича, П. Жук, М. Здобнова.

Таким образом, день 23 июня 1919 года стал датой рождения комсомольской организации Оренбуржья $[6$, д. 11, л. 6; 7, д. 54, л. 6].

Первое время количество комсомольцев было немногочисленно, так как «большинство пролетарской молодежи было на фронте, а та, которая была здесь тогда, не осознавала задач своего союза» [6, д. 11, л. 6]. Большой трудностью на первых порах существования РКСМ являлась слабая организационная поддержка со стороны партийных органов: «Отсутствие инструкций из центра тормозило работу» и пролетарской молодежи приходилось идти огульно [6, д. 11, л. 6]. Правда ситуация изменилась после принятия в августе 1919 года совместного постановления ЦК РКП (б) и ЦК РКСМ «О взаимоотношениях Российского Коммунистического Союза Молодежи и Российской Коммунистической партии большевиков». Оно подчеркивало особую роль комсомола как боевого помощника и резерва Коммунистической партии, четко определило организационные принципы партийного руководства комсомолом. Получая самостоятельность в решении практических вопросов, широкий простор для инициативы и творчества, комсомольские организации постоянно обогащались идейным и организационным руководством партии и указаниями ее выборных органов. Постановление обязывало всех членов РКП (б) до 20 лет вступать в РКСМ, предлагало всем партийным организациям создавать комсомольские ячейки на предприятиях, в городах и селах [2, с. 22].

После выхода данного постановления работа Оренбургского губкома партии как непосредственного наставника комсомольцев приобрела широту, оперативность и действенность. Возросла роль и комсомольской организации, ряды комсомольцев Оренбуржья пополнились большим отрядом молодых коммунистов, что способствовало политическому сплочению и укреплению организации, улучшению идеологической работы среди членов РКСМ [2, с. 22-23].

В августе 1919 года в Оренбурге прошла «Неделя 
красной молодежи» с целью массового вовлечения местной молодежи в комсомол [1, с. 20]. Рост рядов комсомольской организации подготовил основу для создания районных комитетов РКСМ в Оренбурге. Это облегчало партийное руководство комсомолом и молодежью, усилило взаимосвязь между организацией и широкими массами молодежи. К середине сентября 1919 года в Оренбурге были созданы 7 районных комитетов: 1-й комитет находился в клубе коммунистов, 2-й - в доме купца Атрюкина (школа № 41), 3-й - на Ренде, 4-й - на месте Щепного базара, 5-й - в Новой стройке, 6-й - в Красном городке, 7-й - в районе Красного посада [1, с. 20].

В сентябре 1919 года в Оренбургской комсомольской организации насчитывалось 450 членов, к этому моменту она вела за собой пролетарскую и передовую часть учащейся молодежи, была организованной структурой, через которую партийная организация успешно вовлекала молодежь в активное участие в социалистическом строительстве. Наладилась прочная связь с ЦК РКСМ. Условия для завершения образования городской организации комсомола, таким образом, были налицо. 21 сентября 1919 года в Оренбурге открылась І-ая общегородская конференция РКСМ, были представлены 4 районных комсомольских организации. Участники конференции избрали городской комитет РКСМ и делегатов на II-ой съезд комсомола страны, был намечен план работы на ближайшее будущее [2, с. 22-23].

После конференции состоялось заседание Оренбургского губкома РКП (б), на котором были приняты практические мероприятия в сфере августовского постановления ЦК РКП (б) и ЦК РКСМ. Так было решено установить взаимное представительство партийных и комсомольских органов в руководящих структурах. С этого времени в работе комсомольцев постоянное участие принимали председатель губкома РКП (б) И.А. Акулов и председатель губисполкома А.А. Коростелев, а на партийных, губернских партийных конференциях были представители комсомольской организации [2, с. 23].

Освобождение территории губернии от дутовцев дало возможность организовать ячейки КСМ на территории края. Партийные организации приступили к этой работе, прежде всего, в городах среди рабочей молодежи. Для этого они создавали инициативные группы из молодых коммунистов. Например, 29 сентября 1919 года на заседании Илецкого комитета партии из членов РКП (б) была создана инициативная группа, трудящаяся молодежь Илецка стала вступать в ряды комсомола. Схожий процесс наблюдался и в других городах губернии $[2$, c. 23].

Партийные органы посылали в комсомольские организации лекторов и агитаторов, опытных организато- ров, которые помогали развертыванию политико-массовой работы в молодежной среде. Коммунисты на местах помогали находить средства, помещения и многое другое, необходимое для нормального функционирования молодежных организаций [2, с. 23].

Проходивший в октябре 1919 года II съезд РКСМ большое внимание уделил работе комсомола в сельской местности. В резолюции принятой по отчету ЦК РКСМ, отмечалось, что «съезд обращает особое внимание будущего ЦК на необходимость укрепления в настоящее время работы РКСМ в деревне, ее налаживание, втягивание в союз широчайших масс крестьянской молодежи» $[2$, c. 24].

После II съезда РКСМ началась энергичная работа по созданию комсомола в селах и станицах губернии. В течение октября 1919 года комсомольские организации были созданы в селах Краснохолм, Исаево-Дедово (ныне Октябрьское), Петровском и других. Посланников рабочей комсомолии Оренбурга поддерживала беднейшая крестьянская молодежь. Создание комсомольских ячеек в деревне наталкивалось на ожесточенное сопротивление кулачества [8, с. 12].

Начавшийся процесс формирования организационной структуры комсомола в селах губернии вызвал необходимость создания центрального губернского органа. 30 октября 1919 года было образовано губернское организационное бюро в составе И. Акулова, В. Александрова, С. Далина, Д. Семенова, И. Фрейдлин. Несколько позднее в него вошли А. Коростелев и председатель Урало-Сибирского бюро РКСМ Ф. Плясунов. Председателем оргбюро стал И. Фрейдлин [3, с. 5].

Успешному решению задач направленных на выполнение решений II съезда РКСМ, сплочению всех созданных местных союзов молодежи в единую губернскую организацию РКСМ содействовала III-я губернская партийная конференция, проходившая с 17 по 27 ноября 1919 года. Ее делегаты прослушали доклад члена губоргбюро РКСМ, заведующего политико-просветительным отделом губоргбюро, ведущего агитатора и пропагандиста оренбургской комсомолии С. Далина «О работе среди молодежи». Конференция предложила партийным организациям оказывать всевозможную помощь комсомолу, идти навстречу их самодеятельности, поддерживать их инициативу, потребовала повсеместной и немедленной организации комсомольских ячеек. На основе решений губернской партийной конференции развернулась работа коммунистов по организации широких масс молодежи в комсомол. Начался новый период в жизни комсомола края - период завершения формирования губернской организации РКСМ. 
Таким образом, процесс зарождения и становления Оренбургской губернской комсомольской организации проходил в сложных условиях гражданской войны и послевоенной разрухи на территории региона. Это обстоятельство послужило причиной более позднего создания Союза молодежи в Оренбуржье, чем в других районах страны. Формируя свою собственную молодежную организацию, политически активная рабочая молодежь
Оренбурга и губернии постоянно опиралась на помощь старших из числа руководителей местной организации РКП (б) - ВКП (б), исполнительных органов Советов и руководителей системы образования губернии. В дальнейшем комсомолу страны и в том числе в Оренбуржье в 1920-х годах отводилась значительная созидательная роль, что служило мощным стимулом для проявления у союзной молодежи социальной активности.

\section{ЛИТЕРАТУРА}

1. Боевые годы. Сборник воспоминаний и очерков, посвященных 40-летию ВЛКСМ. Оренбург: Оренбургское книжное издательство, 1958. 111 с.

2. Все тебе, Родина! Очерки Оренбургской областной организации ВЛКСМ. 1919 - 1977. Челябинск: Южно-Уральское книжное издательство, 1977.255 с.

3. История образования комсомола в Оренбуржье // Ленинец. 1988. 23 июня.

4. Карпухин 0.И. Сделала ли молодежь свой выбор? (К проблеме социализации молодого поколения современной России) // Социально-гуманитарные знания. 2000. № 4. С. 180-193.

5. Масалимов Р.И. Национальные союзы в Поволжье и на Урале. (1917 - 1928гг). В кн. Востоковедение в Башкортостане. История. Культура. Уфа: Уфимское книжное изд-во, 1998. 241 с.

6. Оренбургский государственный архив социально-политической истории (ОГАСПИ). Ф. 208. Оп. 1. Д. 11.

7. ОГАСПИ. Ф. 209. ОП. 1. Д. 54.

8. Пламенные годы. Даты, цифры и факты из истории Оренбургской областной комсомольской организации. Челябинск: Южно-Уральское книжное издательство, 1968.95 с.

(с) Томина Елена Федоровна (teador17@mail.ru)

Журнал «Современная наука: актуальные проблемы теории и практики»

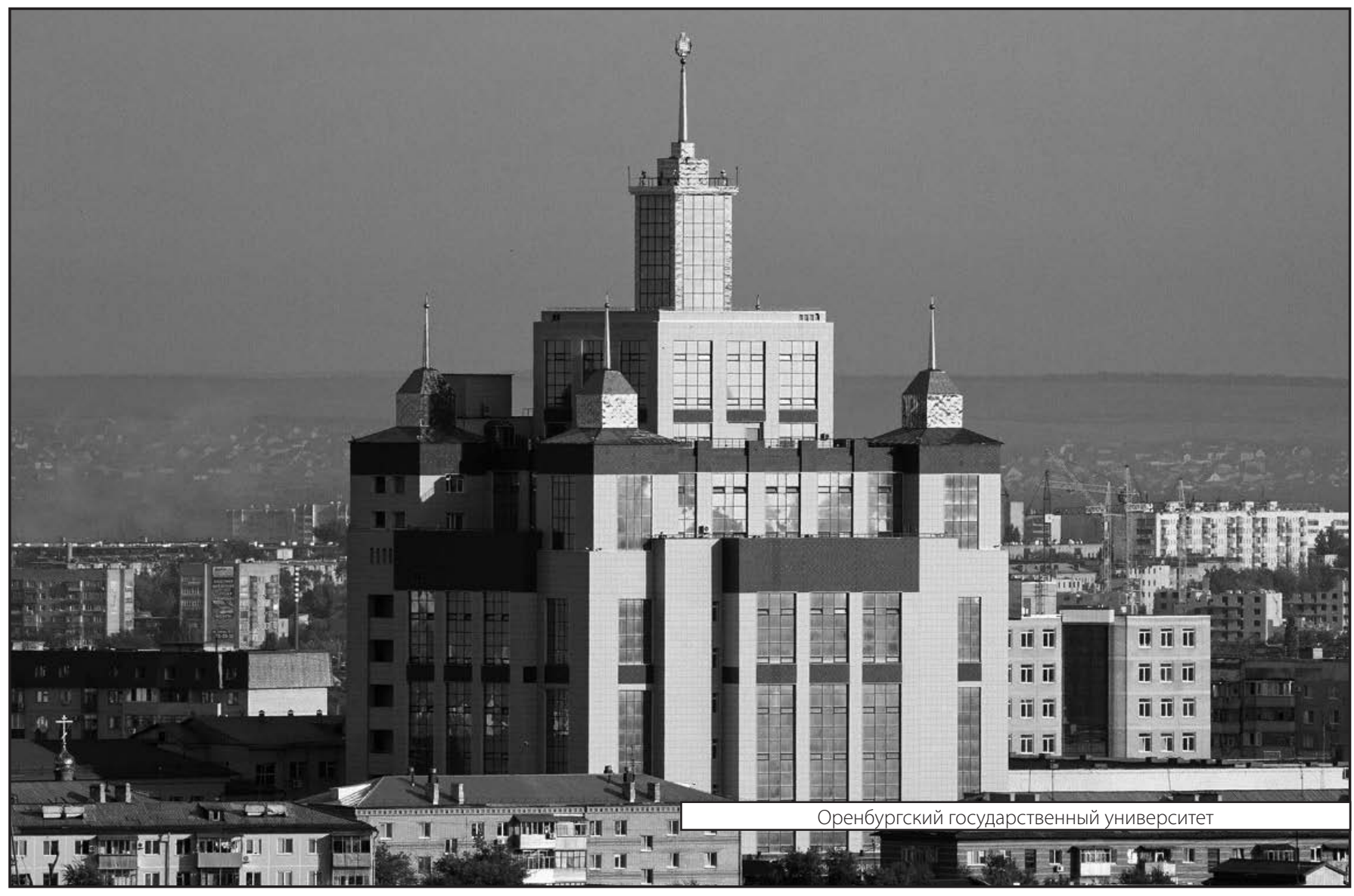

